Ethiopian Journal of Environmental Studies \& Management 7 Suppl.: 765 - 779, 2014.

ISSN:1998-0507

doi: http://dx.doi.org/10.4314/ejesm.v7i1.7S

Submitted: August 15, 2014

Accepted: November 06, 2014

\title{
THE EFFECTS OF FOREST LAND USE AND FRAGMENTATION ON WHITE-THROATED MOUNTAIN BABBLERS (Kupeornis gilberti) A GLOBALLY THREATENED BIRD SPECIES ON THE OBUDU PLATEAU, SOUTHEAST NIGERIA
}

\author{
DANJUMA, D.F.,1, 2 MWANSAT, G. S. ${ }^{2}$ AND MANU, S. A. ${ }^{1,2}$ \\ ${ }^{1}$ A.P. Leventis Ornithological Research Institute, Department of Zoology, University of Jos, \\ PMB 2084, Jos, Nigeria \\ ${ }^{2}$ Department of Zoology, University of Jos, PMB 2084, Jos, Nigeria
}

\begin{abstract}
The Obudu Plateau is the most important single site in Nigeria for some globally threatened bird species like the White-throated Mountain Babbler Kupeornis gilberti, Bannerman's Weaver Ploceus bannermani and Green-breasted Bush-shrike Malaconotus gladiator. It is part of the Cameroon Mountain Endemic Bird Area which has continued to be degraded causing declines in the populations of the threatened bird species but no detailed work has been done to show how forest land use types and fragmentation affect the bird species. This study examined how land use types and fragmentation through changes in patch size and increasing distances between forest patches affect the threatened bird on the Obudu Plateau. Point transect method was used for the bird survey. There was a significant difference in the densities of White-throated Mountain Babblers in the different forest patch categories. As patch size increased, the mean density of White-throated Mountain Babblers also increased but as isolation distance increased, the mean density decreased. Fragmentation negatively affected the threatened bird species. The forest patches with partial protection should be fully protected and there should be some sort of environmental education on the need to protect the forest patches. Suitable trees should be planted in the gaps between the forests.
\end{abstract}

Key Words: Forest land use, fragmentation, threatened bird species, montane forest.

\section{Introduction}

Many of the world's forests are under threat. Despite national and international efforts, the annual loss of forest during the last decades amounted to approximately 15 million hectares worldwide (FAO, 2001). Annual loss of forest area between 2000 and 2005 was 7.3 million hectares per year, an area about the size of Sierra Leon or Panama (FAO, 2005).

Fragmentation is the most important threat to forested ecosystems (Bierregaard, Jnr. et al. 2001) and can occur naturally through fire (Pickett and Thompson, 1978)

*Corresponding Author: Danjuma, D.F.

Email: damidanjuma@yahoo.com and windfall (Foster, 1980), but the most important and large-scale cause is the expansion of human land use (Burgess \& Sharp, 1981). Habitat fragmentation has been implicated as a primary factor in the loss of bird species (Wilcove et al. 1986) but there are species that can persist in a matrix of fragments, secondary undergrowth and large forest patches and can also increase with fragmentation. The level of connectivity between fragmented forest patches has a strong influence on the population dynamics of species residing in these areas (Boudjemad et al., 1999). 
The Effects of Forest Land Use and Fragmentation on White-Throated................DANJUMA et al.

The two important consequences of fragmentation are a reduction in total size of the habitat available and the breaking up of the remaining habitat into patches that are isolated to varying degrees (Wilcove et al., 1986), thereby increasing the vulnerability of biota to environmental and demographic threats (Franklin et al., 2002, Murcia 1995, Ranta et al., 1998, Rolstad 1991, Wilcove et al. 1986). Reduction in habitat leads to species loss (McArthur and Wilson 1967, Beier et al., 2002, Wethered and Lawes, 2003) and montane species are disproportionately threatened because they tend to occupy smaller areas initially compared to the lowland forest (Brooks et al., 1999). Isolation of forest patches disrupts distribution patterns of species and forces individuals to transverse sub-optimal matrix habitat (which might be a threat) between suitable habitat patches, leading to local extinction of bird species (Amburl and Temple, 1983; Ewers and Didham, 2006, Lynch and Whigham, 1984).

Fluctuating asymmetry, the most commonly used estimate of developmental stability are believed to reflect environmental stresses that may negatively affect the bird community better than estimates of population size (Luc et al., 1999). Lens et al. (2002) found that bird occupancy in a forest patch increased with mobility and the tolerance to deterioration of the habitat.

Habitat fragmentation is recognized as a major threat to wildlife population worldwide (Rosenberg, et al., 1997; Harrison and Bruna, 1999). Habitat fragmentation and disturbance may also have implications for biodiversity conservation and can affect a variety of population and community processes over a range of temporal and spatial scales (Saunders, et al., 1991; Debinski and Holt, 2000; Fahrig, 2003). However, separating the effects of each causal process can be challenging because the effects of habitat fragmentation often co- vary with the effects of local human disturbance (Villard, et al., 1999; Caley, et al., 2001; Haila, 2002) and different organisms and ecosystems may experience the degree of fragmentation and disturbance in variable, even contradictory, ways (Haila, 2002; Henle et al., 2004).

White-throated Mountain Babbler (Kupeornis gilberti) is globally threatened bird species with a global status of being endangered (Borrow and Demey, 2004) and has a small range in the montane forests of the Cameroon Mountains EBA at of altitude 950-2,050 (Stattersfield et al., 1998). The species belongs to order Passeriformes, family Timaliidae and subfamily Timalinae (Collar and Stuart, 1985). The White-throated Mountain Babbler has only been recorded in a few localities in western Cameroon and eastern Nigeria (Collar and Stuart, 1985). The type specimen was first collected in 1948 at 1,520 M on Mount Kupe (Collar and Stuart 1985). In Nigeria the species is only known from the Obudu Plateau at 1,520 m where it was discovered in 1953 when six specimens were collected (Collar and Stuart, 1985). Numbers are not known but it is usually found in the canopy of primary forest, although it is occasionally seen in mature secondary growths (Collar and Stuart, 1985). The species is mainly insectivorous and the birds search for food in moss, epiphytes and crevices in bark (Collar and Stuart, 1985).

The Obudu Plateau is the most important single site in Nigeria for globally threatened bird species and is one of the only two montane areas in Nigeria (BirdLife International 2000). This paper describes how fragmentation (particularly patch size and isolation distance) and forest land use affects the density and distribution of Whitethroated Mountain Babbler on the Obudu Plateau. This is the first study to assess the effects of fragmentation and land use of montane forest on White-throated Mountain Babbler of the Obudu Plateau, Nigeria. 
Records of other globally threatened bird species of the Obudu Plateau will be publish elsewhere.

\section{Materials and Methods Study Site}

The Obudu Plateau $\left(6^{\circ} 30^{\prime} \mathrm{N} 9^{\circ} 15^{\prime} \mathrm{E}\right)$ is an afro-montane region with an area of 720 ha situated in Cross River State, south eastern Nigeria, close to the border with Cameroon. The Plateau is part of the Cameroon Mountain Endemic Bird Area (EBA) and is an Important Bird Area (IBA). The area is wet, mountainous and consists of vast areas of montane grasslands (than the original area) covering valleys and hills that supply patches of relict mountain forests with water (Ezealor, 2001). The montane grassland is both original and anthropogenic. Anthropogenic activities such as clearing of forest for farmlands, fuel wood extraction and logging have fragmented this area, resulting in a mosaic landscape containing some patches of high quality forest, dominated by forest species such as Andropogon distachyos, various Ficus species, Polyscias fulva, and the tree fern Cyathea manniana with a humidity that promotes rich vegetation of epiphytes on trunks of trees (Ezealor 2002). Today, montane forests on the Obudu Plateau exist only in small patches, mostly in the valleys, surrounded by grasslands covering the rolling hills. However, there is evidence that hilltops earlier were also covered by montane forests and that the grasslands were derived from human activities such as burning, farming and grazing of livestock (Elgood et al., 1994).

\section{Field Survey}

Six forest patch categories (less disturbed- accessibility is difficult and little anthropogenic activity occurs except hunting; completely protected- no human activity; and partially protected- dead wood and selective logging allowed; houses inside- forest patches with houses inside; farming insideforest patches with farmlands and completely degraded by nomadic activity) were identified based on their level of protection and type of human impact on the forest patch. The actual sizes of the forest patches were determined by walking round each forest patch using the tract $\log$ of the Garmin Global Positioning System (GPS Map 60). Isolation distances were measured in the field as the shortest distance between two forest patches.

Point transects were used to count birds (Bibby et al., 2001). All forest patches were traversed using the Garmin Global Positioning System (GPS MAP 60) track log to generate waypoints and maps of all 31 forest patches. Each forest patch was named coded, saved on the GPS and downloaded to the computer. Using the Map source program points were laid out systematically to cover the forest interior, forest edge and surrounding grasslands. Points were laid at least $100 \mathrm{~m}$ apart. Points were downloaded to the GPS so that they could be identified in the field during survey.

Every morning (between 6.00am and 11.00am) of survey, a different forest patch was surveyed from July 2005 and October 2006. At each point, a 3-minute settling time was allowed before birds were recorded. All bird species and number of individuals heard or seen using a pair of Binoculars was recorded and the perpendicular distance to perched bird species was taken using a laser range finder. The duration of recording was 4 minutes.

\section{Statistical Analysis}

The Distance software version 5.0 Release 2 was used to calculate density of the threatened bird species in each forest patch (http://www.ruwpa.st-and.ac.uk/distance).

One-way analysis of variance (ANOVA) was used to statistically test the variation in density of the threatened bird species among patch sizes, patch isolation distances and 
The Effects of Forest Land Use and Fragmentation on White-Throated................DANJUMA et al.

forest patch categories. General Linear relationships between patch sizes, isolation Models (GLM) was used to check distance and patch category.

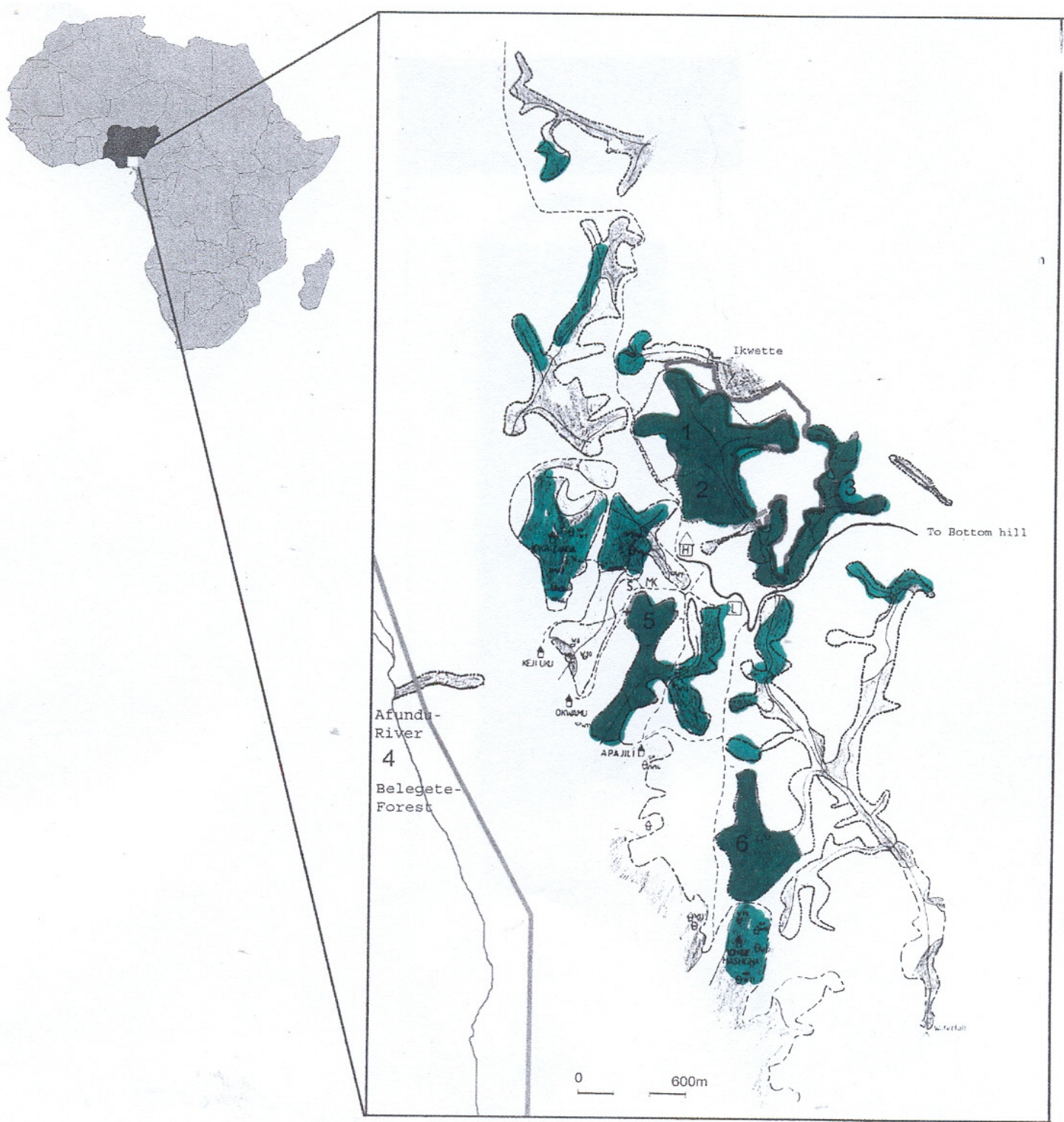

Figure 1: Study Site Showing Surveyed Forest Patches in Green (Remodelled after Rodenkirchen, 2002)

\section{RESULTS}

Effects of Patch Size on Density of Whitethroated Mountain Babbler

Table 1 shows the density of Whitethroated Mountain Babblers in the different forest patches. The minimum patch size in which White-throated Mountain Babblers were found was 3.4ha. As patch size increased, density of White-throated
Mountain Babblers also increased as shown in the interactive graph between the density of Babblers and the different forest patches with different patch sizes (Figure 2).

Effects of Isolation Distance on Density of White-throated Mountain Babbler

Table 2 shows the density of Whitethroated Mountain Babblers in different forest patches with different isolation 
distances. The least isolation distance in which no White-throated Mountain Babbler density was calculated was distances above $240 \mathrm{~m}$. There was no significant difference in the density of White-throated Mountain Babblers across different isolation distances (One-Way ANOVA, $\mathrm{F}_{1,}{ }_{29}=2.59, \mathrm{P}=0.12$, adjusted $\mathrm{R}^{2}=0.082$ ). The density of Whitethroated Mountain Babblers decreased with increase in isolation distance (Figure 3).

\section{Effects of Land Use Types on White- throated Mountain Babblers}

Mean density of White-throated Mountain Babblers showed significant differences among the forest patches with different forest land use types (One-way ANOVA, $\mathrm{F}_{5}, 25=89.6, \mathrm{p}<0.001$, adjusted $\mathrm{R}^{2}=0.93$ ). Density of White-throated Mountain Babblers in each forest patch with different land use types is shown in Table 3. Balegete forest patch that was less disturbed had the highest density of 33.26 Whitethroated Mountain Babblers per hectare while Usmaila forest patch that is degraded by cattle grazing activity had the least density of 0.78 White-throated Mountain Babblers per hectare. Intact and Anape forest patches, partially protected forest patches, namely, Etoto with houses inside, Mile One, Avasie Agese and Holy Mountain with farms inside and Yaya A, Yaya B, Yara A, Yaro B, Aeroplane A, Aeroplane B, Aeroplane C, Mile One, Yaro Overside, Farm Fresh, Woodwork, Fulani Area and Baker's Camp forest patches that were degraded by cattle grazing activity had no White-throated Mountain Babblers. Figure 4 shows the mean densities in each forest land use type.

\section{Discussion}

Analysis of variance (ANOVA) showed a significant difference in the mean density of White-throated Mountain Babblers in the different forest patch sizes $\left(\mathrm{F}_{1,25}=37.16\right.$, $\mathrm{p}<0.001$, adjusted $\left.\mathrm{R}^{2}=0.595\right)$. The species being forest interior and insectivorous, adverse effects of decreasing patch sizes are explicitly found in them (Bender et al., 1998 and Korfanta et al., 2012). Also the density of babblers increased with an increase in patch size (Table 1 and Figure 1). This agrees with the findings of MacArthur and Wilson (1967), Andren (1994), Newmark (1991), Beier et al. (2002), Fahrig (2003) and Wethered and Lawes (2003) that found patch size to have an effect on species. Aside from habitat loss, the reduction in average habitatpatch size that results from fragmentation may limit bird populations. Some remnants of habitat may be too small to accommodate species' territory requirements, and several studies have found that many forest birds require parcels of habitat much larger than their territory size on which to settle and reproduce (Robinson and Bolen, 1989). These species are referred to as "areasensitive" (Robbins et al., 1989) because their densities decline as patch size gets smaller and they are rare or absent in small habitat patches (Table 1). Exception was found in Etoto forest patch (19.6 ha) where no single record of the Babblers was made (Table 1). This might be due to the fact that Etoto forest patch has houses inside, which is the biggest settlement on the Obudu Plateau and thus a lot of disturbances ranging from tree felling to fuel wood extraction. Prugh et al. (2008) found area sensitivity to be higher in landscapes with human-dominated matrix types than areas with natural matrix types. White-throated Mountain Babblers were only found in forest patches greater than 3.3 ha (Table 1). Patches less than 3.3 ha were badly degraded and did not have the large trees and the associated moss plants.

There was no significant difference in the mean density of White-throated Mountain Babblers with different isolation distances. The highest distance between two forest patches was 920 meters (Table 2), so that might be the reason why significant difference statistically was not found. Also 
The Effects of Forest Land Use and Fragmentation on White-Throated................DANJUMA et al.

the species has high mobility and the corridors observed in this study make it likely to survive in fragmented landscapes with low isolation distance (Lens et al., 2002; Thomas, 2000). Their densities decreased with an increase in isolation distance (Figure 2). These are forest species and moving through large open habitats is probably difficult for them. But observations were made of the species using trees that link forest patches as corridors. Other studies have demonstrated that the distance between forest patches has an effect on the number of bird species (Vuilleumier, 1970; Johnson, 1975 and Opdam, et al., 1984) and are prone to extinction (Amburl and Temple, 1983; Lynch and Whigham, 1984; Ewers and Didham, 2006). This could be as a result of factors such as inability to disperse, which disrupts species distribution patterns and forces the species to transverse a matrix habitat that separates suitable habitat fragments from one another.

Corridors provided by the Eucalyptus trees connecting Becheve Nature Reserve and Emba and Golf course forest patches were used by White-throated Mountain Babblers to move between forest patches (pers. Obser.). This agrees with the findings of Hill, (1995) that linear strips of rain forest vegetation are potential dispersal corridors for rain forest insects and that intuitive conservation response is to connect isolated fragments with corridors of suitable habitat. Gilbert, et al., (1998); Rosenberg et al., (1998); Haddad and Baum (1999); Mech and Hallett (2001); Tewksbury et al. (2002) also found that corridors maintain species richness in fragmented landscapes.

A significant difference was observed in the mean density of White-throated Mountain Babblers in the different forest patch categories. There densities was highest in less disturbed forest patches, followed by completely protected, partially protected, patches with houses inside, patches degraded by nomadic and farming activities (Figure 3 ). The outliers (Okezor, Boka and Usmaila forest patches) observed in the forest patches degraded by nomadic activities were densities of the Babblers that was actually recorded; the forest patches were degraded quite well but still had a number of large tree stands with moss plants that the Whitethroated Mountain Babblers utilize, they were large in size and far from human habitation. Etoto forest patch had no record of White-throated Mountain Babblers (Table 1). This could be due to human disturbance as the largest village in the Ranch had most of the large trees cut down.

The difference in the mean density of White-throated Mountain Babblers between protected and unprotected forest patches (Figure 3) showed similarities to the findings by Daily et al., (2001) where higher bird numbers were recorded in native protected habitats. The species is associated with moss plants and epiphytes, where they search for food (Collar and Stuart, 1985) and these are mainly found in the protected forest patches of Obudu Plateau. Habitat loss through different land use change have been identified as drivers of biodiversity loss and are estimated to affect $89 \%$ of all threatened birds (Hilton-Taylor, 2000 and Sala, 2000).

Different forest land use types on the Obudu Plateau have been found to affect the threatened bird species in various ways. White-throated Mountain Babblers were more affected by forest disturbance. Forest patches with greater disturbance had lower densities of the species. For example the babblers were not recorded in one of the forest patches (Etoto) with houses inside throughout the period of the study.

Fragmentation negatively affected the threatened bird species. The density of the bird species was higher in larger forest fragments while increase in isolation distance between the fragments showed a decrease in the density of bird species. 
It is recommended that partially protected forest patches of Golf course, Emba, Grotto, Kejiku, Opazanga and Anape should be completely protected so that the protected forest patches will be large, and allow regeneration to occur in the newly protected patches. This will also greatly reduce the present threats of timber extraction, firewood collection and hunting.

Trees native to the Obudu Plateau and other exotics should be planted and maintained on the Ranch as they serve as connections or corridors between forest patches that help the movement of the babblers.Existing extotic trees on the Plateau that serve as corridors should be maintained. Finally, forest blocks should be planted with exotic and native trees that will be used by the community for their timber and firewood to reduce the pressure on indigenous trees in the forest patches.

\section{Acknowledgements}

Nigerian Conservation Foundation (NCF) with support from the Royal Society for the Protection of Birds (RSPB) funded this research. Joe, Peter, Goddy and Columbus assisted with fieldwork.

\section{References}

Amburl, B. andTemple, S. A. 1983. Areadependent changes in bird communities and vegetation of southern Wisconsin forest. Ecology 64: 1057-1068.

Andren, H. 1994. Effects of habitat fragmentation on birds and mammals in landscapes with different proportions of suitable habitat: a review. Oikos 71: 355-366.

Beier, P., Van Drielen, M. \& Kankam, B. O. 2002. Avifauna collapse in West African forest fragments. Conservation Biology 16: 1097-1111.

Bender, D. J., Contreras, T. A. and Fahrig, L. 1998. Habitat loss and population decline: A meta-analysis of the patch size effect. Ecology 79: 517-533.
Bibby, C. J., Burgess, N. D., Hill, D. A. \& Mustoe, S. H. 2001. Bird Census Tecniques. Academic Press, London. 302pp.

Bierregaard, Jr. R. O., Gascon, C., Lovejoy, T. E. \& Mesquita, R. 2001. Lessons from Amazonia: The Ecology and Conservation of Fragmented Forest. Yale University Press, London. 478pp. BirdLife International (2000). Threatened birds of the world. Barcelona and Cambridge, UK:

Lynx Edicions and BirdLife International. 852pp.

Borrow, N and Demey, R. (2004), Field guide to the birds of western Africa. Christopher Helm, London. 510pp

Boudjemad, K., Lecomte, J. and Clobert, J. 1999. Influence of connectivity on demography and dispersal in two contrasting habitats: an experimental approach. Journal of Animal Ecology 68: 1207-1224.

Brooks, T. M., Pimm, S. T., Kapos, V. and Ravilious, C. 1999. Threat form deforestation to montane and lowland birds and mammals in insular Southeast Asia. Journal of Animal Ecology 68: 1061-1078.

Burgess, R. L. and Sharp, D. M. 1981. Forest island dynamics in man dominated landscapes. SpringerVerlag, New York, U.S.A. 239pp

Caley, M. J., Buckley, K. A., and Jones, G. P. 2001. Separating ecological effects of

habitat fragmentation, degradation, and local loss on coral commensals. Ecology 82: 3435-3448.

Collar, N. J. and Stuart, S. N. 1985. Threatened Birds of Africa and related Islands The ICBP/IUCN Red Data Book. International Council For Bird Preservation (ICBP) and Interntional Union For Conservation of Nature and Natural Resouces., Cambridge, UK and Gland, Switzerland. 761pp. 
The Effects of Forest Land Use and Fragmentation on White-Throated................DANJUMA et al.

Daily, G. C., Ehrlich, P. R. and SanchezAzofeifa, G. A. 2001. Countryside biogeography: use of human dominated habitats by the avifauna of southern Costa Rica. Ecological Applications 11: 1-13.

Debinski, D. M. and Holt, R. D. 2000. A survey and overview of habitat fragmentation experiments. Conservation Biology 14: 342-355.

Ewers, R. M. and Didham, R. K. 2006. Confounding factors of species responses to habitat fragmentation. Biological Review 88: 117-142.

Ezealor, A. U. 2001. Nigeria. In Fishpool, L. D, C. \& Evans, M. I., eds. Important bird areas of Africa and associated islands: priority sites for conservation.

Newbury and Cambridge, UK; Pisces Publications and BirdLife International (BirdLife Conservation Series No. 11). 673-692pp.

Ezealor, A. U. 2002. Critical Sites for Biodiversity Conservation in Nigeria. Nigerian Conservation Foundation, Lagos. 110pp.

Fahrig, L. 2003. Effects of habitat fragmentation on biodiversity. Annual Review of

Ecology, Evolution and Systematics 34: 487515.

FAO. 2001. Global Forest Resources Assessment 2000, Main Report. FAO Forestry paper 140. FAO, Rome. Pp 562

FAO. 2005. Deforestation continues at an alarming rate. FAO Newsroom, Rome.

Foster, R. B. 1980. Heterogeniety and distribution in tropical vegetation. Conservation biology: an evolutionaryecological perspective. Sinuar, Sunderland, MA. Pp 453

Franklin, A. B., Noon, B. R. and George, T. L. 2002. What is the effect of fragmentation on birds in western landscapes? Studies in Avian Biology 25: $20-29$

Gilbert, F., Gonzalez, A. \& Evans-Freke, I. 1998. Corridors maintain species richness in fragmented landscapes of a microecosystem. Proceedings of the Royal Society of London series B. 265, 577-582.

Haddad, N. M. and Baum, K. A. 1999. An experimental test of corridor effect on butterfly densities. Ecological Applications 9: 623-633.

Haila, Y. 2002. A conceptual genealogy of fragmentation research: from island biogeography to landscape ecology. Ecological Applications 12: 321-334.

Harrison, S. and Bruna, E. 1999. Habitat fragmentation and large-scale conservation: what do we know for sure? Ecogeography 22: (3), 225-323.

Henle, K., Davies, K. F., Kleyer, M., Margules, C. and Settele, J. 2004. Predictors of species sensitivity to fragmentation. Biodiversity and Conservation 13:

207-251.

Hill, C. J. 1995. Linear strips of rainforest vegetation as potential corridors for rainforest insects. Conservation Biology 9: 1559-1566.

Hilton-Taylor, C. 2000. IUCN Red List of Threatened Species. International Union for the Conservation of Nature, Gland, Switzerland. 765pp.

Korfanta, N. M., Newmark, W. D. and Kauffman, M. J. 2012. Long-term demographic consequences of habitat fragmentation to tropical understory bird community. Ecology 93: (12), 2548-2559.

Johnson, N. K. 1975. Controls of bird species on montane islands in Great Basin.

Lens, L., Dongen, S. V., Norris, K., Githiru, M. and Mattysen, E. (2002). Avian persistence in fragmented rainforest. Science 298: 1236-1238. 
Luc L, Stefan van D., Christine, M. W., Thomas, M. B and Erick, M. 1999. Fluctuating asymmetry increases with habitat disturbance in seven bird species of a fragmentated afrotropical forest. Proceedings of the Royal Society, London, B, 266, 12411246.Evolution 29: 545-557.

Lynch, J. F. and Whigham, D. F. 1984. Effects of forest fragmentation on breeding bird communities in Maryland, USA. Biological Conservation 28: 287-324.

Mech, S. G., and Hallett, J. G. 2001. Evaluating the effectiveness of corridors: a genetic approach. Conservation Biology 15: 467-474.

McArthur, R. H. \& Wilson, E. O. 1967. The theory of island biogeography. Princeton University Press, Princeton, New Jersey. 203pp

Murcia, C. 1995. Edge effects in fragmented forest: Implication for conservation. Tree 10: 58-62.

Newmark, W. D. 1991. Tropical forest fragmentation and the local extinction of understory birds in eastern Usambara Mountains, Tanzania. Conservation Biology 5 67-78.

Opdam, P., Van Dorp, D. and Ter Braak, C. J. F. 1984. The effect of isolation on the number of woodland birds of small woods in the Netherlands. Journal of Biogeography 11: 473-478.

Pickett, S. T. A. and Thompson, J. N. 1978. Patch dynamic and design of nature reserves. Biological Conservation 13: 27-37.

Prugh, L. R., Hodges, K. E., Sinclair, A. R. E. and Brashares, J. S. 2008. Effects of Habitat area and isolation on fragmented animal population. Proceedings of the National Academy of Sciences (USA, 105 : (52), 2077020775.
Ranta, P., Blom, T., Niemela, J., Joensun, E. and Siitonen, M. 1998. The fragmented Atlantic rain forest of Brazil: size, shape, and distribution of forest fragments. Biodiversity and Conservation 7: 385-403.

Robinson, L. R. and Bolen, E. G. (1989). Wildlife ecology and management. Macmillan Publishing Company, New York. 639pp.

Rodenkirchen, K. (2002). Map prepared for Nigerian Conservation Foundation (NCF), Wildlife Conservation Society (WCS) \& Biodiversity Research Program. Printed March, 2002 at the Cartographic Unit, Cross River State Forestry Commission.

Rolstad, J. 1991. Consequences of forest fragmentation on the dynamics of bird populations: conceptual issues and evidence. Journal of the Linean Society of London, series B, 249-263.

Rosenberg, D. K., Noon, B. R. and Meslow, E. C. 1997. Biological corridors: form, function and efficacy. Bio-science 47: 677-687.

Rosenberg, D. K., Noon, B. R., Megahan, J. W. and Meslow. E. C. 1998. Compensatory behavior of Ensatina eschscholtzii in biological corridors: a field experiment. Canadian Journal of Zoology 76: 117-133.

Sala, O. E. 2000. Biodiversity: global biodiversity scenarios for the year 2100 . Science 287: 1770-1774.

Saunders, D. A., Hobbs, R. J. and Margules, C. R. 1991. Biological consequences of ecosystem fragmentation: a review. Conservation Biology 5: 18-32.

Tewksbury, J. J., Levey, D. J., Haddad, N. M., Sargent, S., Orrock, J. L., Weldon, A., Danielson, B. J., Brinkerhoff, J., Damschen, E. I. and Townsend, P. 2002. Corridors affect plants, animals, and their interactions in fragmented landscapes. Proceedings of the National 
The Effects of Forest Land Use and Fragmentation on White-Throated................DANJUMA et al.

Academy of Sciences of the USA 99: 12923-12926.

Thomas, C. D. 2000. Dispersal and extinction in fragmented landscapes. Proceedings of the Royal Society of London B 267: 139-145.

Villard, R., Trzcinski, M. K. and Merriam, G. 1999. Fragmentation effects on forest birds: Relative influence on woodland cover and the configuration on landscape occupancy. Conservation Biology 13: 774-783.

Vuillemier, F. 1970. Insular biogeography in continental regions. The northern
Andes of South America. American Naturalist 104: 373-388.

Wethered, R. \& Lawes, M. J. 2003. Matrix effects on bird assemblages in fragmented Afromontane forest in South Africa. American Naturalist 104: 373-388.

Wilcove, D. S., McLellan, C. H. \& Dobdon, A. P. 1986. Habitat fragmentation in the temperate zone, pp237-256. In: Conservation Biology: the science of scarcity and diversity. Sinauer, Sunderland, MA.

Table 1: Density of White-throated Mountain Babbler in Different Forest Patches

\begin{tabular}{lll}
\hline & & Density of White-throated Mountain \\
Forest Patch & Patch size (ha) & Babblers (Numbers/Hectare) \\
\hline Yaya B & 0.3 & 0.00 \\
Yaya A & 0.5 & 0.00 \\
Mile One Extention & 0.7 & 0.00 \\
Yaro B & 0.7 & 0.00 \\
Intact & 0.8 & 0.00 \\
Aeroplane Field B & 0.8 & 0.00 \\
Mile One & 0.9 & 0.00 \\
Yaro Overside & 1.2 & 0.00 \\
Farm Fresh Forest & 1.2 & 0.00 \\
Yaro A & 1.6 & 0.00 \\
Aeroplane Field A & 1.7 & 0.00 \\
Aeroplane Field C & 2.5 & 0.00 \\
Woodwork Forest & 3.3 & 0.00 \\
Usmaila Forest & 3.4 & 0.78 \\
Fulani Area & 3.8 & 0.00 \\
Grotto & 4.2 & 0.99 \\
Boka's & 4.6 & 1.82 \\
Apergili & 5.9 & 1.58 \\
Avasie Agese & 6.9 & 0.00 \\
Okpazange & 7.4 & 2.67 \\
Baker's camp & 7.6 & 0.00 \\
Anape A Forest & 8.6 & 0.00 \\
Okezor & 9 & 6.23 \\
Holy Mountain & 9.3 & 0.00 \\
Kejeku & 10.1 & 1.98 \\
Emba & 10.5 & 1.47 \\
Golf Course & 17.8 & 4.44 \\
Etoto & 19.6 & 0.00 \\
Becheve Nature Reserve & 22.9 & 2.15 \\
Becheve Nature Reserve Extension & 23.3 & 3.83 \\
Balegete & 40 & \\
& & 774 \\
\end{tabular}


Table 2: Density of White-throated Mountain Babblers in Forest Patches with Different Isolation Distances

\begin{tabular}{|c|c|c|}
\hline Forest Patch & $\begin{array}{l}\text { Isolation distance } \\
\text { (m) }\end{array}$ & $\begin{array}{l}\text { Density of White-throated Mountain } \\
\text { Babblers (Numbers/hectare) }\end{array}$ \\
\hline Boka's camp & 7 & 1.82 \\
\hline Golf Course & 10 & 4.44 \\
\hline Grotto & 10 & 0.99 \\
\hline Okezor & 11 & 6.23 \\
\hline Apergili & 40 & 1.58 \\
\hline Ettoto & 40 & 0.00 \\
\hline Farm Fresh Forest & 40 & 0.00 \\
\hline Balegete & 43 & 33.26 \\
\hline \multicolumn{3}{|l|}{ Becheve Nature Reserve } \\
\hline Extension & 48 & 4.83 \\
\hline Becheve Nature Reserve & 54 & 2.15 \\
\hline Woodwork Forest & 54 & 0.00 \\
\hline Kejeku & 65 & 1.98 \\
\hline Okpazange & 65 & 2.67 \\
\hline Emba & 74 & 1.47 \\
\hline Anape A Forest & 136 & 0.00 \\
\hline Intact & 205 & 0.00 \\
\hline Holy Mountain & 230 & 0.00 \\
\hline Usmaila Forest & 230 & 0.78 \\
\hline Aeroplane Field B & 240 & 0.00 \\
\hline Aeroplane Field C & 240 & 0.00 \\
\hline Baker's camp & 297 & 0.00 \\
\hline Aeroplane Field A & 318 & 0.00 \\
\hline Yaro Overside & 345 & 0.00 \\
\hline Mile One Extention & 381 & 0.00 \\
\hline Fulani Area & 416 & 0.00 \\
\hline Yaro B & 420 & 0.00 \\
\hline Yaro A & 420 & 0.00 \\
\hline Mile One & 517 & 0.00 \\
\hline Avasie Agese & 610 & 0.00 \\
\hline Yaya B & 610 & 0.00 \\
\hline Yaya A & 923 & 0.00 \\
\hline
\end{tabular}


The Effects of Forest Land Use and Fragmentation on White-Throated................DANJUMA et al.

Table 3: Density of White-throated Mountain Babblers in Forest Patches With Different Land Use Types.

\begin{tabular}{lll}
\hline Forest Patch & Forest Land Use Type & $\begin{array}{l}\text { Density of White-throated Mountain } \\
\text { Babblers (Numbers/Hectare) }\end{array}$ \\
\hline Balegete & 0 & 33.26 \\
Becheve Nature Reserve & 1 & 2.15 \\
Becheve Nature Reserve & & \\
Extension & 1 & 4.83 \\
Intact & 2 & 0.00 \\
Grotto & 2 & 0.99 \\
Okpazange & 2 & 2.67 \\
Anape A Forest & 2 & 0.00 \\
Kejeku & 2 & 1.98 \\
Emba & 2 & 1.47 \\
Golf Course & 2 & 4.44 \\
Apergili & 3 & 1.58 \\
Etoto & 3 & 0.00 \\
Mile One Extension & 4 & 0.00 \\
Avasie Agese & 4 & 0.00 \\
Holy Mountain & 4 & 0.00 \\
Yaya B & 5 & 0.00 \\
Yaya A & 5 & 0.00 \\
Yaro B & 5 & 0.00 \\
Aeroplane Field B & 5 & 0.00 \\
Mile One & 5 & 0.00 \\
Yaro Overside & 5 & 0.00 \\
Farm Fresh Forest & 5 & 0.00 \\
Yaro A & 5 & 0.00 \\
Aeroplane Field A & 5 & 0.00 \\
Aeroplane Field C & 5 & 0.00 \\
Woodwork Forest & 5 & 0.00 \\
Usmaila Forest & 5 & 0.78 \\
Fulani Area & 5 & 0.00 \\
Boka's & 5 & 1.82 \\
Baker's camp & 5 & 0.00 \\
Okezor & 5 & 6.23 \\
\hline & &
\end{tabular}


Ethiopian Journal of Environmental Studies and Management Vol. 7 Suppl. 2014

Figure 2: Relationship Between White-throated Mountain Babblers and Patch size. 
The Effects of Forest Land Use and Fragmentation on White-Throated................DANJUMA et al.

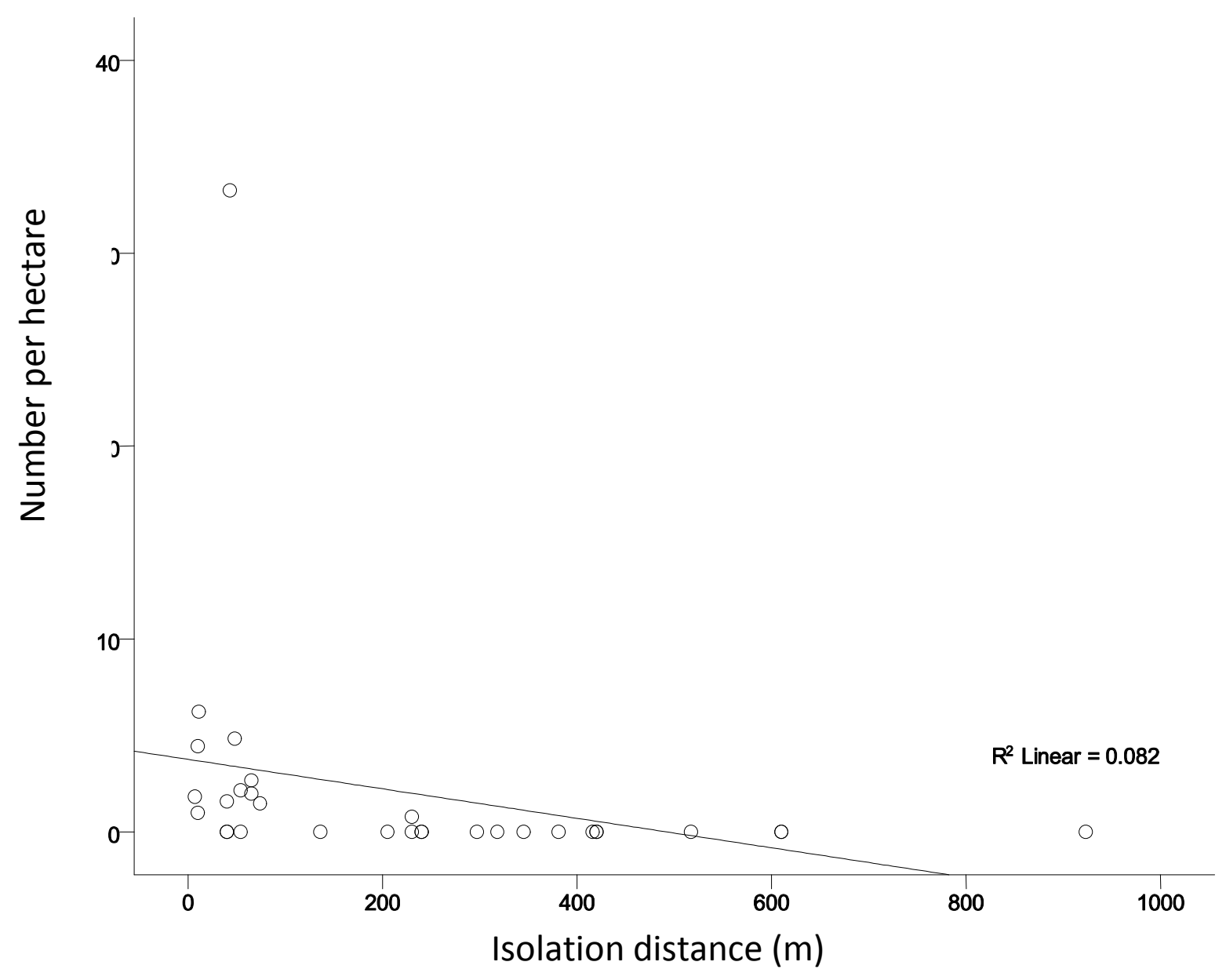

Figure 3: Density of White-throated Mountain Babblers in Relation to Isolation Distances 
Ethiopian Journal of Environmental Studies and Management Vol. 7 Suppl. 2014

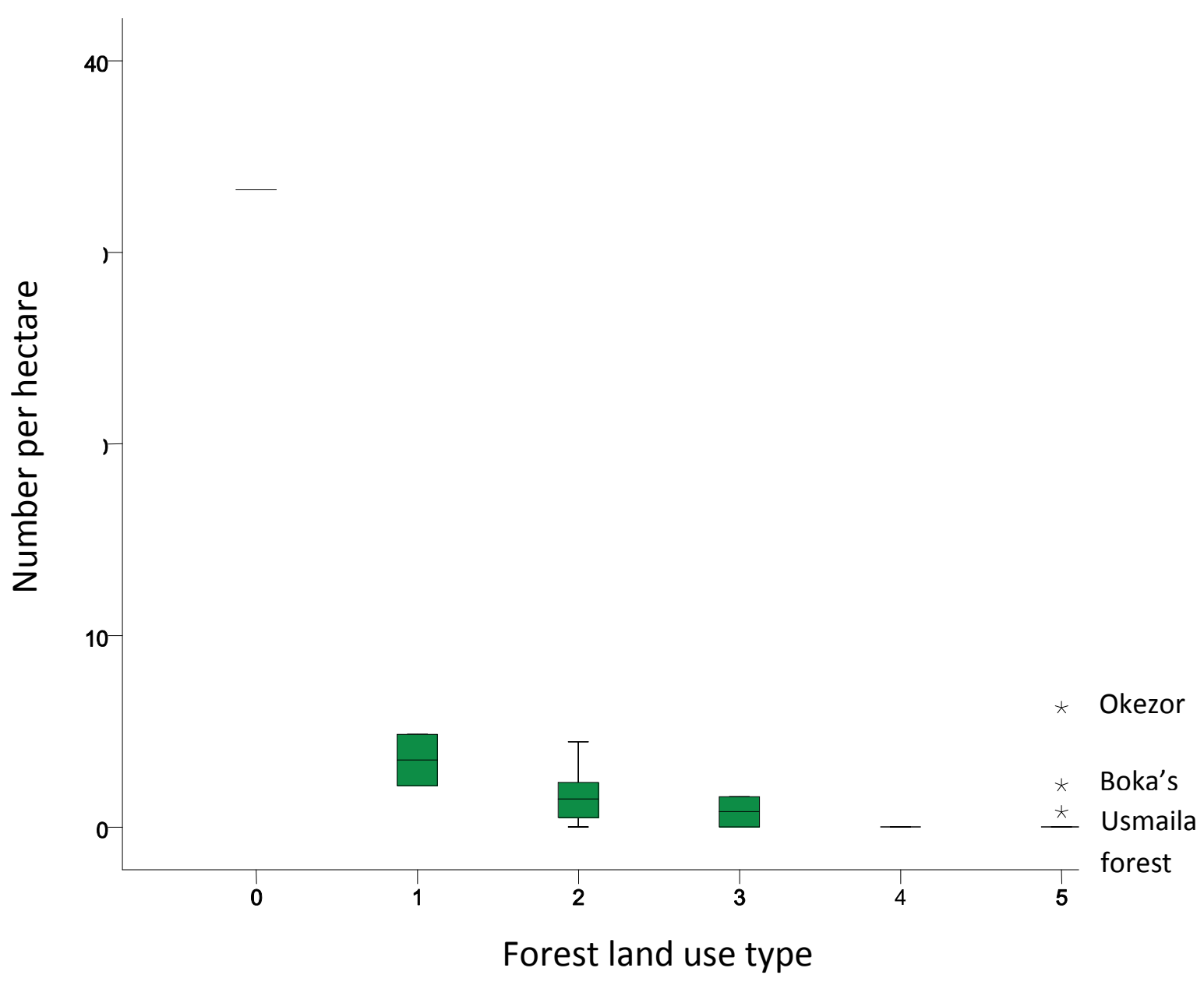

Figure 4: Density of White-throated Mountain Babblers in Different Forest Patch Categories 